\title{
The influence of texturing process parameters on yield points and breaking forces of pes filament yarns
}

\author{
DOI: $10.35530 / I T .069 .04 .1466$
}

PETAR STOJANOVIĆ

DUŠAN TRAJKOVIĆ

JOVANA STEPANOVIĆ

NATAŠA RADMANOVAC

JOVAN STEPANOVIĆ

\section{REZUMAT - ABSTRACT}

\section{Influența parametrilor procesului de texturare asupra punctelor limită de elasticitate și forțelor} de rupere ale firelor filamentare Pes

O analiză a proprietăților mecanice ale firelor PES texturate arată că viteza de texturare are un efect semnificativ asupra acestor proprietăți. Rezultatele au arătat că, odată cu creșterea vitezei de texturare, sa observat o tendință descrescătoare a forțelor de rupere ale firelor PES texturate analizate, la grade de întindere de 1,665 și 1,685. Unele deviații ale rezultatelor au fost găsite în cazul firelor PES texturate cu gradul de întindere aplicat de 1,675. De asemenea, rezultatele au arătat că, la un grad de întindere de 1,685, firele analizate au în general valori mai mari ale forțelor de rupere. Aplicarea unui grad mai mare de întindere a firelor filamentare PES îmbunătățește orientarea lanțurilor moleculare în direcția forței de întindere, ceea ce contribuie la îmbunătățirea caracteristicilor mecanice ale firelor PES texturate. În plus, rezultatele analizei influenței temperaturii arată că, la temperaturi mai ridicate, se produc fire PES texturate cu valori mai mari ale forțelor de rupere. Rezultatele obținute au fost utilizate pentru a determina ecuațiile pentru estimarea punctelor limită de elasticitate și a forțelor de rupere ale firelor filamentare PES texturate în funcție de parametrii de proces ai producției.

Cuvinte-cheie: fir texturat, viteză de texturare, forța de rupere, punct limită de elasticitate

\section{The influence of texturing process parameters on yield points and breaking forces of pes filament yarns}

An analysis of the mechanical properties of textured PES yarns shows that the texturing speed has a significant effect on these properties. The results showed that with the increase in the texturing speed, a decreasing trend was observed in the breaking forces of the analyzed textured PES yarns at stretching degrees of 1.665 and 1.685. Some deviations of the results were found in the textured PES yarns with the applied stretching degree of 1.675. Also, the results showed that at a stretching degree of 1.685, the analyzed yarns generally have higher values of breaking forces. Applying a higher degree of stretching of PES filament yarns improves the orientation of molecular chains in the direction of the stretching force, which contributes to better mechanical characteristics of textured PES yarn. In addition, the results of the analysis of the influence of the first heater temperature show that, at higher temperatures, the textured PES yarns with higher values of breaking forces are produced. The results obtained were used to suggest the equations for predicting the yield points and breaking forces of textured PES filament yarns depending on the process parameters of production.

Keywords: textured yarn, texturing speed, breaking force, yield point

\section{INTRODUCTION}

During the development and production of textured PES fibers, great attention in the research was devoted to finding and explaining the dependence between the parameters of the texturing process and the structure of the textured filament, that is, the dependence between structure and properties. Texturing is a process with numerous parameters and the polyester filament texturing parameters significantly influence its behavior during further processing, and all the errors and irregularities created in the texturing process become easily visible in finished products.
This problem is particularly pronounced when texturing a partially oriented PES filament (POY - Partially Oriented Yarn), on which there is not much data in the reference works. They mainly refer to the texturing process in laboratory conditions [1-3]. A significantly higher number of papers is devoted to texturing of extruded polyester filaments (FOY - Fully Oriented Yarn) that is characterized by a stable structure and lower sensitiveness to parameter changes in the texturing process, but also the use of different texturing processes [4-7]. 
The modern texturing machines use contactless high temperature heaters (HT heaters) [8-10]. Although heater temperatures (usually $380^{\circ} \mathrm{C}$ to $420^{\circ} \mathrm{C}$ for texturing PET filament of $167 \mathrm{dtex}$ at texturing speed of $1000 \mathrm{~m} / \mathrm{min}$ ) are considerably above polymer softening (about $230-240^{\circ} \mathrm{C}$ ) and melting (about $260^{\circ} \mathrm{C}$ ) temperatures, yarn retention time in the heater is short so the yarn temperature at heater exit is in the range of normal operating temperatures (about $210^{\circ} \mathrm{C}$ ) [9]. Due to such high operating temperatures retention time in the heating zone ranges, depending on the yarn speed and heater length, from 0.12 to $0.072 \mathrm{~s}$. During such short retention time yarn must be heated above glass transition temperature, where temperature distribution across the cross section of multifilament yarn must be uniform, in order to obtain textured yarn of uniform properties. Increasing the temperature of the heater results in a more intense heating of the yarn, the retention time of the yarn in the heater is reduced and therefore the temperature drop over the cross-section of yarn [10-11]. It was noted that the temperature difference between the surface and the core of the yarn is increased with increasing heater temperature, texturing speed and reducing yarn fineness while the temperature difference is decreased with increasing the length of the heater [10].

Since the textured filament POY PES yarns, produced on machines with HT heaters, are insufficiently studied, in the scope of this work presented are the investigations of the influence of some texturing process parameters on the yield points and breaking forces of textured PES filaments.

The results obtained can be used for the selection of optimum production parameters of the yarns in industrial conditions. Moreover, the results contributed to suggest equations for predicting the yield points and breaking forces of PES filament yarns at various process parameters.

\section{EXPERIMENTAL WORK}

\section{Materials and methods}

Experimental part of the work includes the analysis of breaking forces of POY multifilament polyester yarn of fineness $167 f 3 \times 1 d$ tex. The textured PES yarn of fineness $167 f 36 \times 1 \mathrm{dtex}$, was produced under industrial conditions from POY PES multifilament of fineness $278 f 36 \times 1$ dtex, and obtained from TWD Fibers, Germany. The texturing was made on a stretching friction texturing machine with high temperature heater: FTF-15 (ICBT, France).

The texturing of yarn was performed using varying temperatures of the first heater $\left(350^{\circ} \mathrm{C}, 400^{\circ} \mathrm{C}\right.$ and $450^{\circ} \mathrm{C}$ ) maintaining the constant temperature of the second heater $\left(180^{\circ} \mathrm{C}\right)$, then with varying values of surface speed of disks to yarn speed ratios (2.15, 2.20 and 2.25) and by changing stretching degrees in texturing zoone $(1.665,1.675$ and 1.685$)$, at texturing speeds of $500 \mathrm{~m} / \mathrm{min}, 600 \mathrm{~m} / \mathrm{min}, 700 \mathrm{~m} / \mathrm{min}, 900$ $\mathrm{m} / \mathrm{min}, 1000 \mathrm{~m} / \mathrm{min}$ and $1100 \mathrm{~m} / \mathrm{min}$.

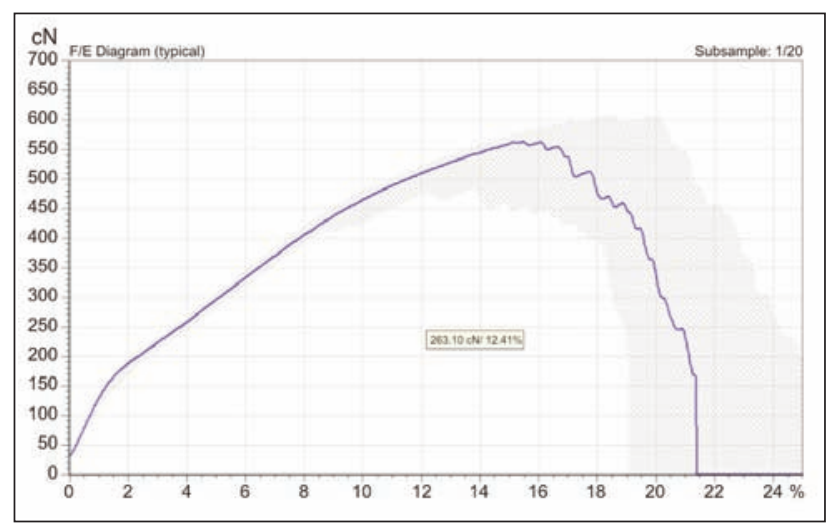

Fig. 1. Typical curve F-e textured PES yarn

For determination of breaking characteristics of experimental material automatic dynamometer USTER TENSORAPID 4 was used. The breaknig force of yarn was determined according to DIN 53384. Further, based on funcion F-e (figure 1) it was determinated the value of the force in the yiled point, which was numerically determined in the maximum of the first derivative of the curve $F(e)$, where is $F^{\prime \prime}(e)=0$. Up to this point, textured PES filament yarns exhibits higher resistance to stretching forces. Then, a faster deformation is set in, up to material destruction.

\section{RESULTS AND DISCUSSION}

The influence of texturing speed on the breaking force of PES filament yarn

The texturing speed causes the changes in the structure of filament yarns, which affect the mechanical characteristics of these yarns. Changing the texturing speed affects the time of contact between the yarn and heaters, the cooling and stabilization time of the textured PES yarn.

In figures 2 to 10 shown there are the changes of breaking characteristics of textured filament PES yarns at various texturing speeds, temperatures of the first heater and $D / Y$ ratios.

The results show that, as the texturing speed increases, a decreasing trend is observed in the value of the breaking forces of the analyzed yarns. By applying a stretching degree of 1.675 , the tendency of reducing the breaking force with an increase in the texture speed to $900 \mathrm{~m} / \mathrm{min}$ is observed in most cases, and then a growth trend of the breaking force is observed.

At the same time, in figures 1 through 9, histograms are shown illustrating the effect of the change of the individual texturing parameters on the values of the breaking forces of textured PES filament yarn. The results show that at a stretching degree of 1.685 the analyzed yarns generally have higher values of breaking forces, at higher texturing speeds, i.e., at speeds of $900 \mathrm{~m} / \mathrm{min}, 1000 \mathrm{~m} / \mathrm{min}$, and $1100 \mathrm{~m} / \mathrm{min}$. This is explained by the fact that the stretching of filament PES yarns improves the orientation of the macromolecules in the direction of the stretching force, which contributes to better mechanical characteristics of these yarns. 


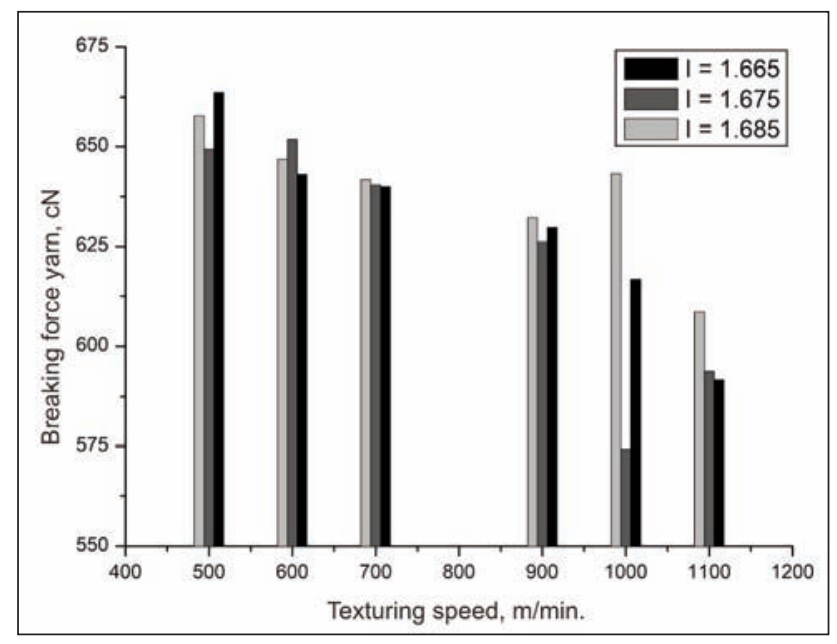

Fig. 2. The influence of the texturing speed on the breaking force of yarn (Samples $1-18 ; \mathrm{T}=350^{\circ} \mathrm{C} ; \mathrm{D} / \mathrm{Y}=2.15$ )

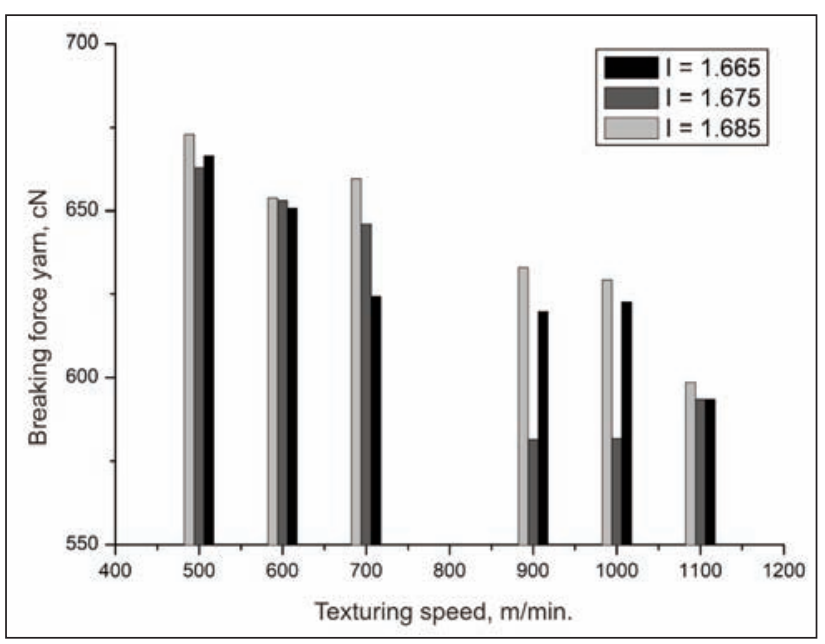

Fig. 4. The influence of the texturing speed on the breaking force of yarn (Samples $37-54 ; \mathrm{T}=350^{\circ} \mathrm{C} ; \mathrm{D} / \mathrm{Y}=2.25$ )

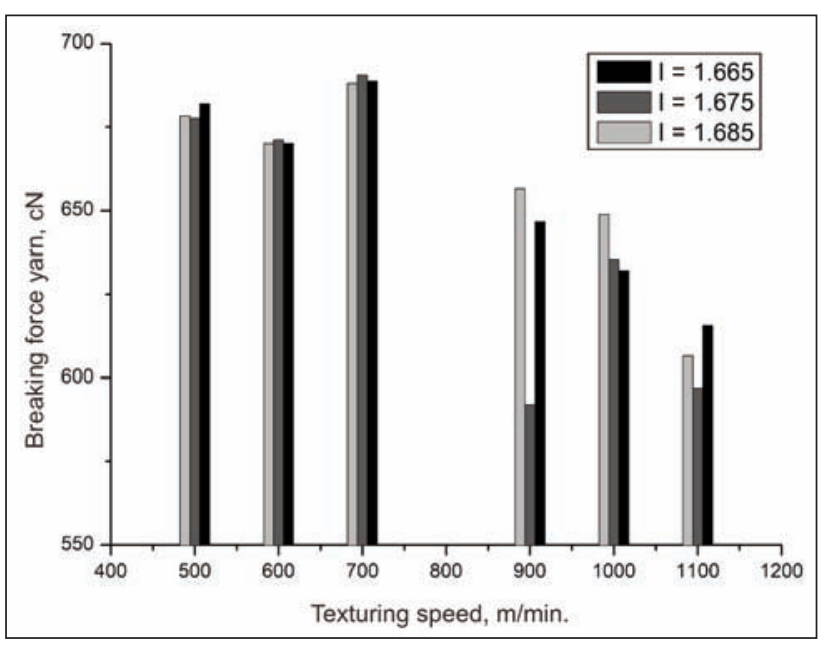

Fig. 6 . The influence of the texturing speed on the breaking force of yarn (Samples $73-90 ; \mathrm{T}=400^{\circ} \mathrm{C} ; \mathrm{D} / \mathrm{Y}=2.20$ )

The influence of the first heater temperature on the breaking force of PES filament yarn

In figure 11 given there are the total graphs of the variations of the breaking force of the textured PES

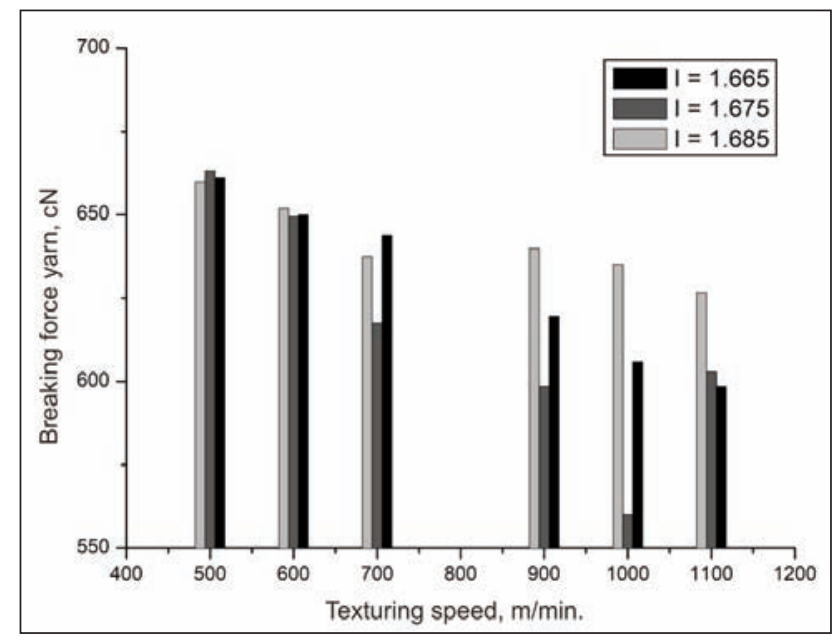

Fig. 3. The influence of the texturing speed on the breaking force of yarn (Samples 19-36; $\mathrm{T}=350^{\circ} \mathrm{C} ; \mathrm{D} / \mathrm{Y}=2.20$ )

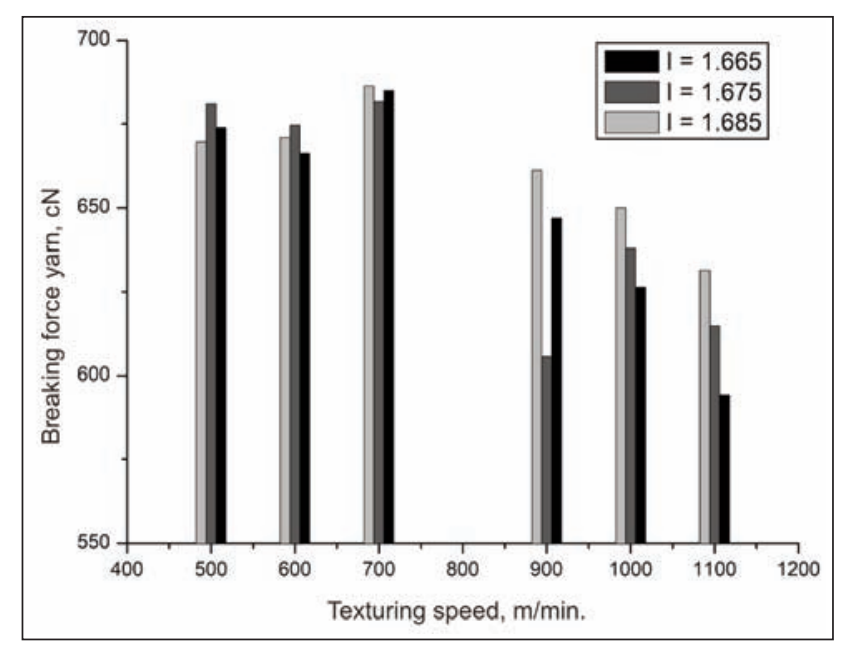

Fig. 5. The influence of the texturing speed on the breaking force of yarn (Samples $55-72 ; \mathrm{T}=400^{\circ} \mathrm{C} ; \mathrm{D} / \mathrm{Y}=2.15$ )

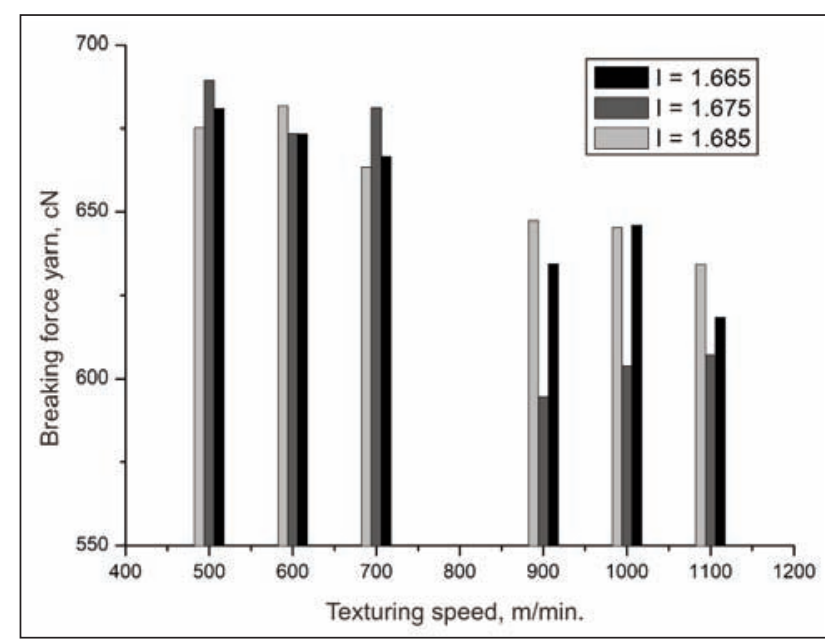

Fig. 7. The influence of the texturing speed on the breaking force of yarn (Samples $91-108 ; \mathrm{T}=400^{\circ} \mathrm{C} ; \mathrm{D} / \mathrm{Y}=2.25$ )

yarn as dependent on the temperature of the first heater and the texturing speed.

The obtained results show that, generally, at higher temperatures of the first heater, textured PES yarns with the higher breaking force are produced. In the 


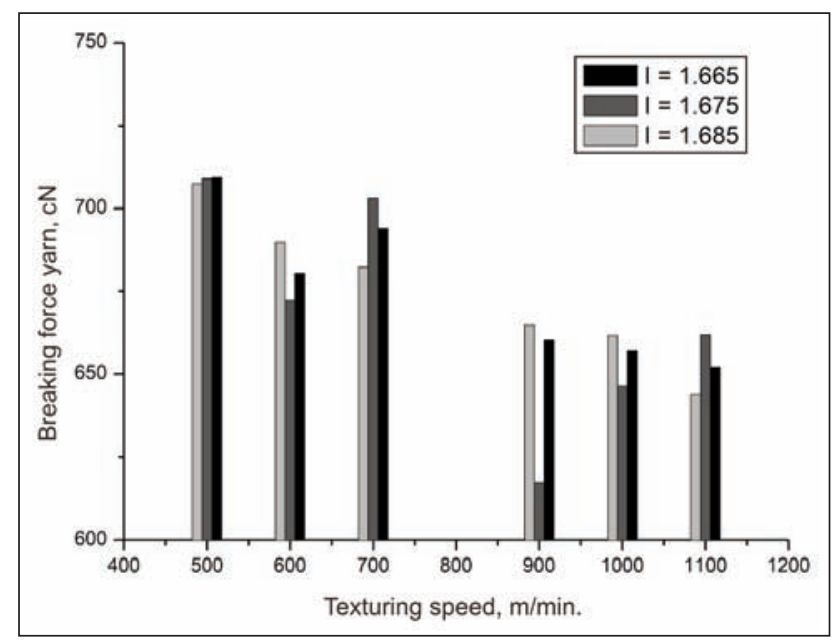

Fig. 8. The influence of the texturing speed on the breaking force of yarn (Samples 109-126; $\mathrm{T}=450^{\circ} \mathrm{C} ; \mathrm{D} / \mathrm{Y}=2.15$ )

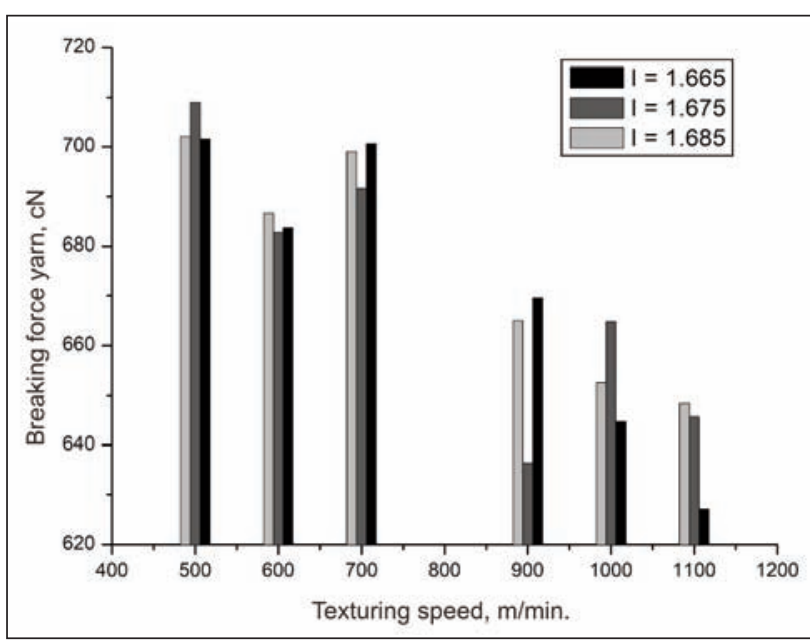

Fig. 9. The influence of the texturing speed on the breaking force of yarn (Samples $127-144 ; \mathrm{T}=450^{\circ} \mathrm{C} ; \mathrm{D} / \mathrm{Y}=2.20$ )

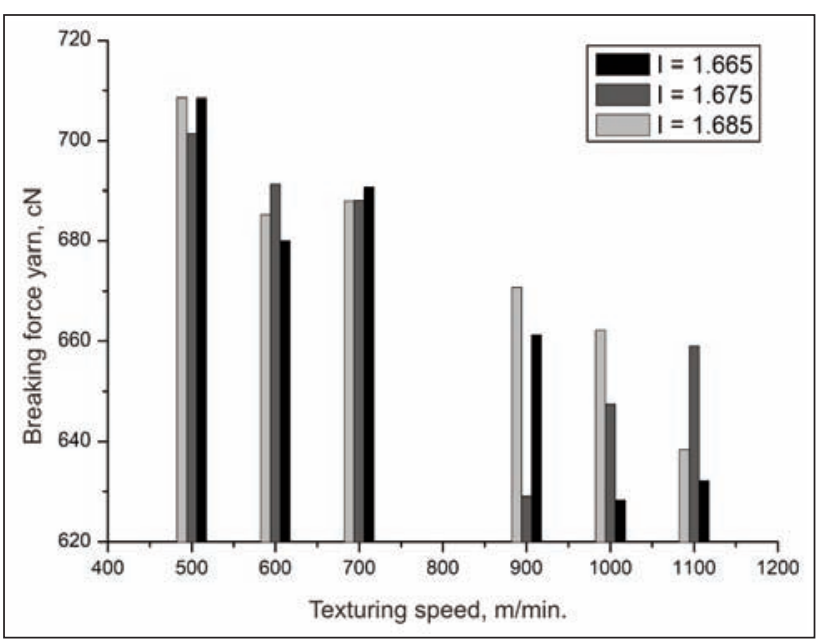

Fig. 10. The influence of the texturing speed on the breaking force of yarn (Samples $145-162 ; \mathrm{T}=450^{\circ} \mathrm{C} ; \mathrm{D} / \mathrm{Y}=2.25$ )

texturing process, the mobility and flexibility of molecular chains increases at higher temperatures, which is reflected in their orientation in the direction of the tensile force, and consequently in the values of the breaking forces of textured PES filament yarns.
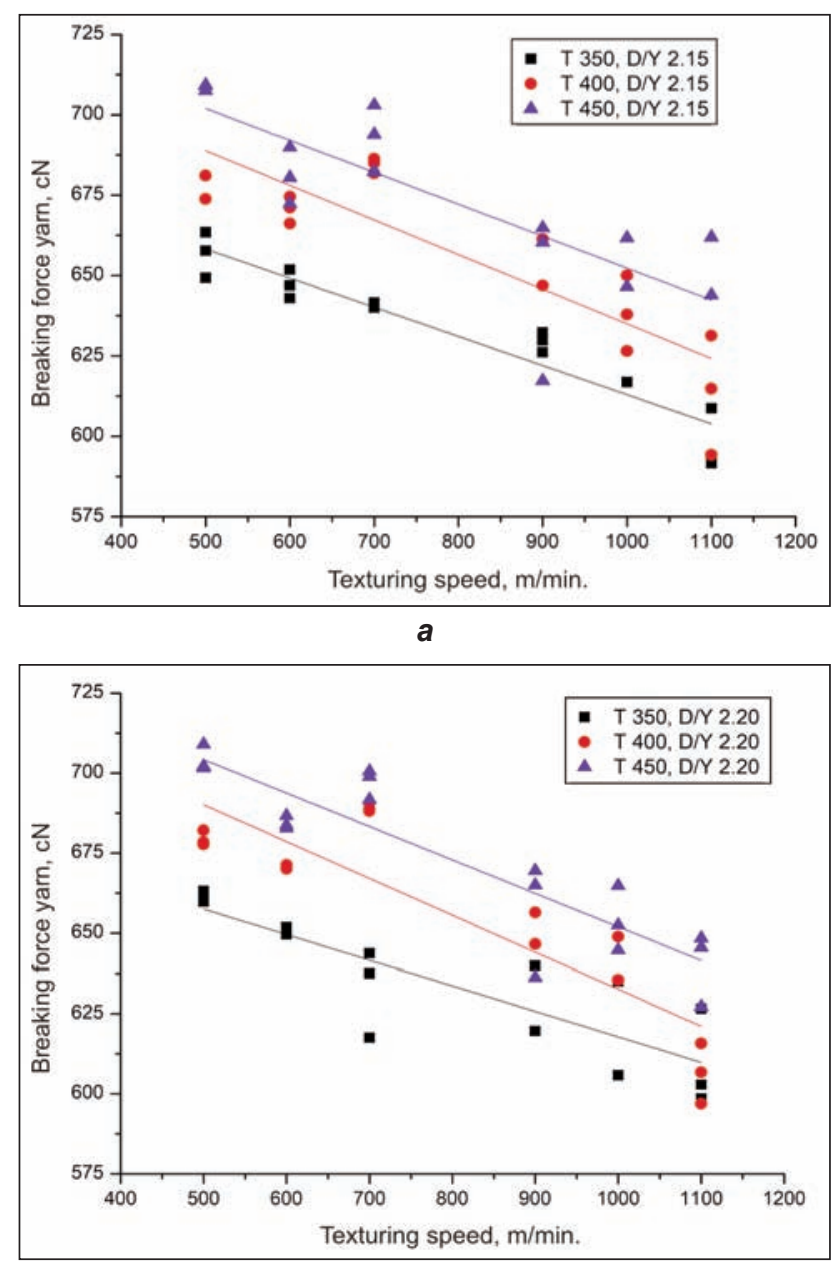

b

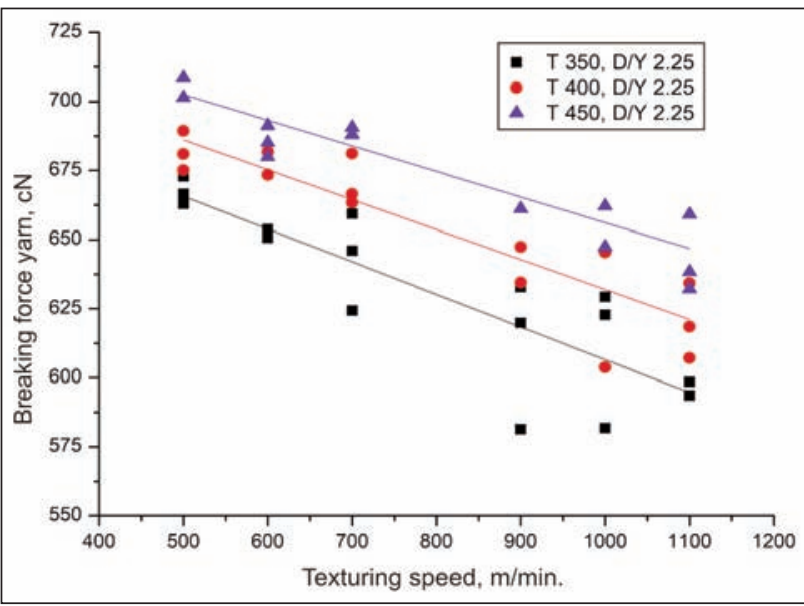

c

Fig. 11. The influence of the texturing temperature on the breaking force of yarn:

$a-\mathrm{D} / \mathrm{Y}=2.15 ; b-\mathrm{D} / \mathrm{Y}=2.20 ; c-\mathrm{D} / \mathrm{Y}=2.25$

Prediction of the yield points and breaking forces of the textured PES filament yarns

Table 1 shows the parameters of the regression equation that can be used for the prediction of the breaking forces of the textured yarns with the stretching degree of 1.665 depending on the texturing speed for given first heater temperatures and $D / Y$ ratios, while table 2 contains the corresponding equation parameters for the stretching degree of 1.685 in the texturing process. 


\begin{tabular}{|c|c|c|c|c|c|}
\hline \multicolumn{7}{|c|}{ REGRESSION EQUATION PARAMETERS (STRETCHING DEGRE 1.665) } \\
\hline \multirow{2}{*}{ Samples } & \multicolumn{5}{|c|}{$\boldsymbol{F}_{\boldsymbol{b}}=\boldsymbol{a}+\boldsymbol{b} \boldsymbol{v}$ [cN] } \\
\cline { 2 - 6 } & $\mathbf{R}^{\mathbf{2}}$ & $\boldsymbol{a}$ & Standard error & $\boldsymbol{b}$ & Standard error \\
\hline $1-18$ & 0.88872 & 710.29762 & 12.87334 & -0.09939 & 0.01554 \\
\hline $19-36$ & 0.99206 & 715.62857 & 3.55359 & -0.10729 & 0.00429 \\
\hline $37-54$ & 0.81143 & 709.42143 & 17.41356 & -0.09971 & 0.02101 \\
\hline $55-72$ & 0.74076 & 750.56667 & 26.96918 & -0.12725 & 0.03255 \\
\hline $73-90$ & 0.81100 & 746.62619 & 19.83547 & -0.11343 & 0.02394 \\
\hline $91-108$ & 0.88242 & 731.64762 & 13.0696 & -0.09789 & 0.01577 \\
\hline $109-126$ & 0.83114 & 747.61429 & 14.76029 & -0.09014 & 0.01781 \\
\hline $127-144$ & 0.82490 & 766.11905 & 19.83444 & -0.11861 & 0.02394 \\
\hline $145-162$ & 0.87527 & 770.14762 & 17.81412 & -0.12914 & 0.0215 \\
\hline
\end{tabular}

Table 2

\begin{tabular}{|c|c|c|c|c|c|}
\hline \multicolumn{7}{|c|}{ REGRESSION EQUATION PARAMETERS (STRETCHING DEGRE 1.685) } \\
\hline \multirow{2}{*}{ Samples } & \multicolumn{5}{|c|}{$\boldsymbol{F}_{\boldsymbol{b}}=\mathbf{a}+\boldsymbol{b} \boldsymbol{v}$ [cN] } \\
\cline { 2 - 6 } & $\mathbf{R}^{\mathbf{2}}$ & $\boldsymbol{a}$ & Standard error & $\boldsymbol{b}$ & Standard error \\
\hline $1-18$ & 0.60616 & 685.17143 & 16.42928 & -0.05846 & 0.01983 \\
\hline $19-36$ & 0.80488 & 679.17143 & 8.32408 & -0.04671 & 0.01005 \\
\hline $37-54$ & 0.87879 & 726.47619 & 14.48376 & -0.10668 & 0.01748 \\
\hline $55-72$ & 0.56666 & 713.73095 & 19.66077 & -0.06514 & 0.02373 \\
\hline $73-90$ & 0.64151 & 740.71667 & 27.12734 & -0.10325 & 0.03274 \\
\hline $91-108$ & 0.90723 & 718.24286 & 8.84859 & -0.07543 & 0.01068 \\
\hline $109-126$ & 0.96253 & 750.64524 & 6.88545 & -0.09454 & 0.00831 \\
\hline $127-144$ & 0.87354 & 750.90238 & 13.08121 & -0.09411 & 0.01579 \\
\hline $145-162$ & 0.89561 & 753.7619 & 12.22992 & -0.09779 & 0.01476 \\
\hline
\end{tabular}

Where: $F_{b}$ is breaking force of the yarn [cN]; $v$ - texturing speed $[\mathrm{m} / \mathrm{min}]$

Table 3

\begin{tabular}{|c|c|c|c|c|c|}
\hline \multicolumn{7}{|c|}{ REGRESSION EQUATION PARAMETERS (FORCE IN THE YIELD POINT) } \\
\hline \multirow{2}{*}{ Samples } & \multicolumn{3}{|c|}{$\boldsymbol{F}_{\boldsymbol{y}}=\mathbf{a}+\boldsymbol{b}_{\boldsymbol{b}} \mathbf{~} \mathbf{c N}$ ] } \\
\cline { 2 - 6 } & $\mathbf{R}^{\mathbf{2}}$ & $\boldsymbol{a}$ & Standard error & $\boldsymbol{b}$ & Standard error \\
\hline $1-18$ & 0.87923 & -329.21577 & 63.55562 & 1.05289 & 0.1003 \\
\hline $19-36$ & 0.67407 & -174.73434 & 90.82439 & 0.80875 & 0.14292 \\
\hline $37-54$ & 0.91199 & -215.92297 & 41.60487 & 0.87777 & 0.06595 \\
\hline $55-72$ & 0.82824 & -433.89132 & 90.25481 & 1.17869 & 0.13764 \\
\hline $73-90$ & 0.94363 & -323.32638 & 42.15543 & 1.01664 & 0.06403 \\
\hline $91-108$ & 0.84042 & -391.62645 & 79.92019 & 1.12700 & 0.12205 \\
\hline $109-126$ & 0.64126 & -4.05184 & 67.87856 & 0.52975 & 0.10045 \\
\hline $127-144$ & 0.60221 & -164.7482 & 99.04516 & 0.76062 & 0.1471 \\
\hline $145-162$ & 0.60263 & -114.60364 & 99.90673 & 0.69625 & 0.14767 \\
\hline
\end{tabular}

Where: $F_{y}$ is force in the yield point $[\mathrm{cN}] ; F_{b}$ - breaking force of the yarn [cN]

The force value at the yield point depending on the temperature of the first heater and the $\mathrm{D} / \mathrm{Y}$ ratio, they can be predicted by using the regression equations whose parameters are shown in table 3 .

The results shown can be used for the selection of the optimal parameters for PES filament yarns texturing.

\section{CONCLUSIONS}

The false twist texturing of POY polyester yarn is a process which includes close interactions between process parameters and the structure and properties of textured yarn. The most significant texturing process parameters are texturing speed and temperature 
of the heater, because both parameters affect the properties of textured yarn.

Analyzing the mechanical properties of textured PES yarns it can be concluded that texturing speed shows a significant impact on these properties. The results showed that with the increase of the texture speed, a decreasing trend in the value of the breaking forces of the analyzed textured PES yarns is observed. In addition, the results showed that at a higher degree of stretching, the analyzed yarns generally have higher values of breaking forces, which is explained by correction of the orientation of molecular chains due to stretching. Also, the results show that, at higher temperatures of the first heater, the textured PES yarns with higher values of breaking forces are produced. At higher temperatures in the texturing process mobility and flexibility of molecular chains are increased contributing to their better orientation in the direction of tensile forces, which reflects on the mechanical properties of textured PES filament yarns.

\title{
BIBLIOGRAPHY
}

[1] Yildirim, K., Altun, S., Ulcay, Y. Relationship between yarn properties and process parameters in false-twist textured yarn, In: J. Engineered Fibers and Fabrics, 2009, vol. 4, nr. 2, pp. 26-32.

[2] Tehran, M.A., Azimi, B., Mojtahedi, M.R.M. Investigating the effect of false twist texturing process on the color coordinates variation of spun-dyed polyester filament yarns, In: J. Engineered Fibers and Fabrics, 2011, vol. 6, nr. 4, pp. 54-62.

[3] Canbaz Karakaşa, H., Dayıoğlu, H. Influence of false-twist texturing parameters on the structural properties of polyester yarn, In: Indian Journal of Fibre \& Textile Research, 2005, vol. 30, pp. 37-41.

[4] Celik, P., Ozdil, N., Supure, G., Experimental investigation on the static and dynamic strength of false twist textured polyester yarns, In: Industria Textila, 2011, vol. 62, nr. 1, pp. 38-43.

[5] Bhattacharya, S.S., Shaikh, T.N., Pratap, A. An investigation of thermal characteristic of mechanical crimp textured polyester yarn by Differential Scanning Calorimeter (DSC), In: AIP Conf. Proc. 1249, 2010, pp. 67-74.

[6] Shaikh, T.N., Bhattacharya, S.S. Deriving an empirical formula to determine the optimum level of false-twist in mechanically-crimped textured polyester yarn, In: Textile Research Journal, 2011, vol. 81, nr. 19, pp. $1995-2005$.

[7] Mahish, S.S., Punj, S.K., Kothari, V.K. Comfort and handle related properties of PN blended air-jet textured yarn fabrics, In: Fibers and Polymers, 2010, vol. 11, nr. 6, pp. 932-940.

[8] Demir, A., Behery, H.M. Synthetic filament yarn texturing technology, Prentice Hall, Upper Saddle River, USA, 1997.

[9] Atkinson, C. False twist textured yarns: Principles, processing and applications, Woodhead Publishing Limited, Cambridge, 2012.

[10] Eskin, N. Analysis of a high temperature heater in a false twist texturing process, In: Energy Conversion and Management, 2003, vol. 44, nr. 16, pp. 2531-2547.

[11] Dupeuble, J.C., Texturing performance of polyamide yarn on high temperature heaters, In: Chemiefasern Textilindustrie, 1993, vol. 43, nr. 11, E145-E152.

Authors:

\section{PETAR STOJANOVIĆ 1 \\ DUŠAN TRAJKOVIĆ ${ }^{2}$ \\ JOVANA STEPANOVIĆ 2 \\ NATAŠA RADMANOVAC 2 \\ JOVAN STEPANOVIĆ ${ }^{2}$}

\begin{abstract}
${ }^{1}$ Dunav a.d. Grocka, Bulevar revolucije 15, 11306 Grocka, Serbia
${ }^{2}$ Faculty of Technology, University of Niš/Bulevar oslobođenja 124, 16000 Leskovac, Serbia

e-mail: p.stojanovic@dunavgrocka.rs, dusan@tf.ni.ac.rs, stepanovicjovana@yahoo.com, radmanovac@tf.ni.ac.rs, jovan@tf.ni.ac.rs
\end{abstract}

Corresponding author:

JOVAN STEPANOVIĆ

e-mail: jovan@tf.ni.ac.rs 